\title{
Facial Nerve Monitoring During Parotidectomy: Review
}

\author{
Berna Uslu Coskun ${ }^{1}$
}

\begin{abstract}
:
Facial nerve monitoring during parotidectomy: review

The majority of otolaryngologists perform parotid gland surgery. The understanding of facial nerve anatomy and meticulous surgical technique has always been the prerequisite for this procedure. However, complications still occur by even the most experienced surgeons. Facial nerve monitoring is an adjunctive method available to a surgeon during parotid surgery to assist the functional preservation of the facial nerve. This review describes the goals, applications, technique and benefits of electrophysiologic facial nerve monitoring during parotid surgery.

Keywords: Facial monitoring, facial nerve, parotidectomy

ÖZET:

Parotidektomi sırasında fasiyal sinir monitörizasyonu: Derleme

Kulak burun boğaz doktorlarının büyük kısmı parotis cerrahisini uygulamaktadırlar. Fasiyal sinirin anatomisini anlamak ve titiz bir cerrahi teknik, bu prosedür için gereklidir. Ancak en deneyimli ellerde dahi komplikasyonlar olmaktadır. Fasiyal sinir monitörizasyonu, fasiyal sinirin fonksiyonel olarak korunmasına yardımcı olmak için parotis cerrahisi sırasında cerrah için kullanılabilir yardımcı bir yöntemdir. Bu derlemede parotis cerrahisi sırasındaki hedefleri, uygulamaları, tekniği ve elektrofizyolojik fasiyal sinir monitörizasyonu kullanımının yararlarından bahsedilmektedir.
\end{abstract}

Anahtar kelimeler: Fasiyal monitörizasyonu, fasiyal sinir, parotidektomi

Ş.E.E.A.H. Tıp Bülteni 2017;51(1):8-12

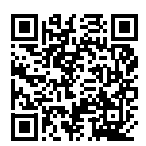

'Sisli Hamidiye Etfal Training and Research Hospital, Department of Otolaryngology, Head and Neck Surgery, Istanbul - Turkey

Address reprint requests to / Yazışma Adresi: Berna Uslu Coskun,

Sisli Hamidiye Etfal Training and Research Hospital, Department of Otolaryngology, Head and Neck Surgery, Istanbul - Turkey

E-mail / E-posta:

bernauslu@gmail.com

Date of receipt / Geliş tarihi:

February 17, 2017 / 17 Şubat 2017

Date of acceptance / Kabul tarihi: February 22, 2017 / 22 Şubat 2017

\section{INTRODUCTION}

Parotis gland surgery is a challenging procedure because of the parotid gland's unique pathology and intimate relationship with facial nerve. Postoperative facial paralysis can be a devastating complication of parotidectomy. Injury can result in impaired eye closure, which can lead to corneal ulceration and consequent blindness as well as cosmetic compromise. For benign parotid tumors, permanent facial nerve paralysis is said to occur in 3-5.6\% of cases (1). Transient weakness is reported to occur in $8-72 \%$ of cases (2). Avoidence of intraoperative nerve injury is of paramount importance in order to reduce patient morbidity. There are numerous factors that may influence facial nerve injury during parotidectomy, including tumor size, type, location, extend of surgery, inflammation, and reoperation. Facial nerve injury mechanisms during parotidectomy include nerve division, stretching, compression, ligature entrapment, thermal and electrical injuries and ischemia. Facial nerve monitoring is an adjunctive and useful method to help the surgeon to avoid the complications.

The purpose of this review is to describe the application of facial nerve monitoring, its benefits, goals, technique, and complications.

Parotidectomy with preservation of the facial nerve is a procedure commonly performed by many otorhinolaryngologists. While it is generally accepted that direct visualization of the nerve is the gold standard, the most popular and recent technique to 
find the facial nerve is to monitor it by specific nerve monitoring.

\section{Applications}

Applications for facial nerve monitoring during parotidectomy includes instances in which facial nerve identification, dissection, and preservation are potentially difficult. Such situations include reoperation, prior radiation therapy, malignant neoplasm, large or deep lobe neoplasm with anatomic distortion, chronic parotitis and minimally invasive surgical procedures such as intraparotid sentinel lymph node biopsy. Similar to its role during parotidectomy, facial nerve monitoring during sentinel lymph node biopsy is useful to confirm the identity of peripheral facial nerve branches and in giving a warning to the surgeon, through mechanical evoked responses, when dissection is performed in close proximity to a facial nerve branch (3). Some surgeons routinely use facial nerve monitoring for all parotid surgeries.

Benefits of routine use of facial nerve monitoring include its intraoperative availability when an unanticipated need for its use arises. Routine use ensures surgeon a familiarity with the nerve monitoring system and facility with methods to resolve the system problems. After an initial learning curve, the surgeon can properly interpret various signals and differentiate artifact from true events. Routine use of nerve monitoring may also result in a reduction in operation time (3). Surgeons may not use facial nerve monitoring during parotid surgery for a variety of reasons. One of these is the expense of the monitoring equipment. The other reason is the lack of training and experience with nerve monitoring. The additional time to set up the monitoring equipment, although minimal, may also be a factor to avoid its use.

There has been no medicolegal precedent mandating the use of facial nerve monitoring technology. However, there is a strong perception that its use may limit the liability of the surgeon in an unfortunate nerve damage. This attitude is reflected in the survey results, that is to say, to the question "why do you use intraoperative nerve monitoring?",
$51 \%$ of responders replied as "for medicolegal protection". Whether this belief is true or not, itcomes down to the issue of "standard care" with respect to that particular surgery $(4,5)$. Interestingly, the results show that many more responders consider monitoring to be the standard of care for parotid and mastoid surgery $(32 \%$ and $37 \%$, respectively) than performing it for thyroid surgery $(15 \%)$. As there has been no study showing a benefit in reducing the rate of nerve damage, it cannot be considered as the standard of care. However, the awareness of this technology and the recognition of its increasing use amongst peers, may lead apperception of its acceptance as the standard of care.

\section{Benefits}

It is a useful method to identify the main trunk. It is also useful when a surgeon is applying a retrograde dissection; to identify peripheral branches. Facial monitoring also helps to distinguish facial nerve from sensory nerve or non-nerve tissue during dissection. After surgical dissection of the facial nerve, electrical stimulation of the nerve with the probe is recommended to allow assessment of the functional integrity of the nerve and aid in prediction of postoperative facial nerve function. Makeieff et al (6) found that, in the setting of parotidectomy for recurrent pleomorphic adenoma, monitoring led to significantly lower rates of facial nerve paresis in the monitored group. In addition, operating time was shorter in the monitored group. Terrell et al. (7) found a significant reduction in temporary paresis rates amongst monitored patients undergoing parotidectomy, but no difference in permanent paresis. Reilley et al. (8) however found no such association. Normal response thresholds typically predict normal facial function. Elevated response thresholds may predict facial paresis of variable degree postoperatively. This information can be beneficial in patient counseling postoperatively. Absent response thresholds indicate either temporary or permanent loss of nerve integrity. Witt (2), has raised questions regarding potential false positive readings, equipment failure, and the extra time and costs inherent to nerve monitoring. He suggests that 
overreliance on the monitoring may lead to a false sense of security and a less gentle surgical technique. However, his parotidectomy case series demonstrated no statistically difference with regard to facial nerve morbidity in monitored versus unmonitored patients. Wolf et al. (9) used facial nerve monitoring in 35 consecutive patients with benign parotid neoplasms and in 4 patients with recurrent benign tumors. Twenty-four similar patients served as controls in this retrospective case series. The authors did not note only a reduction in operative time but also a better facial functional outcome in the monitored group. No patient who had reoperation for recurrent tumor had permanent facial paralysis. Lopez et al. (10) used facial nerve monitoring in 25 patients during parotidectomy. Twenty-seven patients served as case controls in this retrospective study. These authors found that the monitored patients had a statistically significant lower incidence of temporary facial paresis (36\% vs 70\%, p=0.013) and permanent facial paralysis ( $4 \%$ vs $30 \%, p=0.025)$. Doikov et al. (11) reported a retrospective analysis of 15 patients who underwent parotidectomy with facial nerve monitoring using the Neurosign 100 monitor. In all cases, monitoring was successful in locating, identifying and evaluating the integrity of the facial nerve. No postoperative nerve injury was detected clinically.

\section{Facial Nerve Monitoring Goals}

The goals of facial nerve monitoring are early facial nerve identification, warning the surgeon of unexpected facial nerve stimulation, mapping of the course of the nerve and evaluation and prognosis of nerve function at the conclusion of the procedure (12). Recent studies have demonstrated that the majority of otolaryngologists, head and neck surgeons in the United States and in the United Kingdom use nerve monitoring during their surgical training and when they frequently perform parotid surgery (13). In addition, US surgeons who use facial nerve monitoring in their practice are less likely to have a history of a parotid surgery related lawsuit $(3,13)$.

There are 3 goals of intraoperative monitoring.
One is to enhance early nerve identification and the second is to enhance neural preservation by minimizing trauma, and the last one is to assess neural integrity after the procedure is over.

1-Nerve localization: The potential benefits of electrophysiologic facial nerve monitoring during parotidectomy are numerous. The stimulation probe is useful in assisting the surgeon to identify the main trunk of the facial nerve when nerve localization is difficult, to identify a peripheral nerve branch during retrograde facial nerve dissection, and to distinguish facial nerve from sensory nerve or non-nerve tissue during parotid dissection.

2-Detection of neural trauma: Reliance on mechanically evoked responses caused by blunt manipulation and traction will minimize neural trauma. These responses are generated by changes in ion permeability consequent to neural deformation. Cold saline irrigation may also result in these changes. Direct manipulation of the nerve usually results in a single compound muscle action potential synchronous with a surgical maneuver. This is a burst response due to blunt trauma and it is not always time locked and thus the surgeon must interpret this in the context of ongoing surgical events. This is contrary to electrically stimulated response, which is always time locked.

In a study, prolonged dissection caused multipl asynchronous action potentials, which persisted for seconds. Prolonged periods of train potentials may indicate some degree of trauma due to surgical manipulation. Temporary cessation of dissection and release of traction were usually beneficial. The facial nerves that appeared to be relatively active in producing burst EMG activity and maintained this throughout the entire case, exhibited the best early postoperative facial function. But nerves that were or had become quiet with respect to elicitation of burst activity during manipulation appeared to exhibit poor facial nerve function one week after surgery (14).

3-Assessment of neural integrity: At the end of each procedure, stimulating the nerve proximal to 
the site of dissection assessed neural integrity. Electrical stimulus was applied and pulse response was obtained. In an intact nerve, a fraction of the usual current intensity $(0.2 \mathrm{~mA})$ was required to elicit the acoustic response. If the nerve was partially cut, no pulse or burst response was observed indicating no conduction of impulses (14). Any facial muscle movement can cause EMG responses. Repositioning the head or touching the face can cause the movement. These can be triggered by external electrical signals when there is no facial movement, but muting devices in NIM-2 reduce these. Both mono and bipolar electrocautery can produce false alarms, but NIM-2 has a special muting function that cancels these alarms occuring by electrocautery (14).

\section{Technique}

For electrophysiologic monitoring of the facial nerve, neuromuscular blockade should be avoided (15). Needle electrodes are placed in optimal locations to record activity from facial muscles, typically in the 4 areas innervated by the facial nerve: frontal, zygomatic, buccal and marginal mandibular (16). Ground and stimulator anode electrodes are also placed. A stimulation probe is included on the sterile operative field. All electrode wires are connected to an interface circuit box. Stimulus intensity, duration, rate and event threshold are set. Intraoperatively, the surgeon performing the monitoring must differentiate true EMG events from artifacts such as those that occur from contact between surgical instruments in the operative field. EMG waveform characteristics, EMG amplitude, the surgical context of the event aid in this differentiation. A false positive event should be excluded because this may give the surgeon false sense of insecurity. It must be emphasized that the absence of an electrically evoked response does not exclude the possibility that the stimulated tissue is the facial nerve. In this situation, proper system operating function must be confirmed. A false-negative event may give the surgeon a false sense of security. The surgeon must exercise must proper judgment in event interpretation, and anatomic information should always trump physiologic information. Electrosurgical units and other electrical equipment can create an electrical artifact that interferes with facial muscle response recording.

\section{Complications of Facial Nerve Monitoring}

Electrophysiologic facial nerve monitoring is safe. Because electrically evoked facial nerve responses during electrophysiologic facial nerve monitoring are obtained using a pulsed nerve stimulator, facial nerve injury arising from overstimulation that theoretically may occur from prolonged stimulation with a battery-powered direct current nerve stimulator is unlikely (17). Complications of facial nerve monitoring are uncommon. A potential complication is the reliance of the surgeon on a false-negative response with subsequent nerve division. Surgical judgment and anatomic information should always supersede adjunctive information provided with nerve monitoring. Nerve electrodes can result in infection, bleeding, or injury to adjacent structures. These complications are rare with sterile technique and proper needle electrode placement. Needle electrodes are a potential source of injury to the surgical team during both placement and removal. Haengeli et al. (18) reported 3 cases of facial burns related to a technical deficit in a nerve monitoring device.

Facial nerve monitoring during parotid surgery is an adjunctive method to assist the functional preservation of the facial nerve. It is useful, but not essential. It has been suggested that with using facial monitor; the operative time decreased, and the incidence of temporary facial nerve paresis reduced.

\section{REFERENCES}

1. EAR Foundation Facial nerve monitoring: an EAR Foundation Alumni Study. Am J Otol 1996; 17: 162-4.

2. Witt RL. Facial nerve monitoring in parotid surgery: The standard of care? Otolaryngol Head and Neck 1998; 119: 468-70. [CrossRef] 
3. Eisele DW, Wang SJ, Orloff LA. Electrophysiologic facial nerve monitoring during parotidectomy: Clinical review. Head Neck 2010; 32: 399-405.

4. Flukes $S$, Ling SS, Leahy $T$, Sader $C$. Intraoperative nerve monitoring in otolaryngology: A survey of clinical practice patterns. Int J ORL Head and Neck Surg 2013; 2: 21-6. [CrossRef]

5. Angelos P. Recurrent laryngeal nerve monitoring: State of the art, ethical and legal issues. Surgical Clinics of North America 2009; 89: 1157-69. [CrossRef]

6. Makeieff $M$, et al. Continuous facial nerve monitoring during pleomorphic adenoma recurrence surgery. Laryngosvope 2005; 115: 1310-4. [CrossRef]

7. Terrell JE, Kileny PR, Yian C, Esclamado RM, Bradford CR, Pillsbury MS, et al. Clinical outcome of continuous facial nerve monitoring during primary parotidectomy. Archives of Otolaryngology Head and Neck Surgery 1997; 123: 1081-7. [CrossRef]

8. Reilly J, Myssiorek D. Facial nerve stimulation and postparotidectomy facial paresis. Otolaryngology Head and Neck Surgery 2003; 128: 530-3. [CrossRef]

9. Wolf SR, Schneider W, Suchy B, Eichhorn B. Intraoperative facial nerve monitoring in parotid surgery. HNO 1995; 43: 294-8.

10. López M, Quer M, León X, Orús C, Recher K, Vergés J. Usefulness of facial nerve monitoring durşng parotidectomy. Acta Otorhinolaryngol Esp 2001; 52: 418-21.
11. Doikov IY, Konsulov SS, Dimov RS. Stimulation electromyography as a method of intraoperative localization and identification of the facial nerve during parotidectomy: Review of 15 consecutive parotid surgeries. Folia Med 2001; 43: 23-6.

12. Silverstein $H$, Rosenberg S. Intraoperative facial nerve monitoring. Otolaryngol Clin North Am 1991; 24: 709-25.

13. Lowry Tr, Gal TJ, Brennan JA. Patterns of use of facial nerve monitoring during parotid gland surgery. Otolaryngol Head Neck Surg 2005; 133: 313-8. [CrossRef]

14. Kamal SA, Al-Bahkaly SA, Othman EA. Intraoperative monitoring of the facial nerve. Neurosciences 2002; 7: 256-61.

15. Thiede $O$, Klüsener $T$, Sielenkämper A, Van Aken $H$, Stoll $W$, Schmäl F. Interference between muscle relaxation and facial nerve monitoring during parotidectomy. Acta Otolaryngol 2006; 126: 422-8. [CrossRef]

16. Guo L, Jasiukaitis P, Pitts, Cheung SW. Optimal placement of recording electrodes for quantifying facial nerve compound action potential. Otol Neurotol 2008; 29: 710-3. [CrossRef]

17. Love JT Jr, Marchbanks JR. Injury to the facial nerve associated with the use of a disposable nerve stimulator. Otolaryngology 1978; 86: 61-4. [CrossRef]

18. Haenggeli A, Richter $M$, Lehmann W, Dulguerov P. A complication of intraoperative facial nerve monitoring: Facial skin burns. Am J Otol 1999; 20: 679-82. 